\title{
GEOSTATISTICAL APPROACH FOR THE ASSESSMENT OF THE WATER RESERVOIR CAPACITY IN ARID REGIONS: A CASE STUDY OF THE AKDARYA RESERVOIR, UZBEKISTAN
}

Shavkat RAKHMATULLAEV ${ }^{1,2}$, Antoine MARACHE ${ }^{1}$, Frédéric HUNEAU ${ }^{1}$, Philippe LE COUSTUMER $^{1}$, Masharif BAKIEV ${ }^{2}$, Mikael MOTELICA-HEINO ${ }^{3}$

${ }^{1}$ Université de Bordeaux, GHYMAC Géosciences Hydrosciences Matériaux Constructions, B18 avenue des Facultés, 33405 Talence cedex, France

${ }^{2}$ Tashkent Institute of Irrigation and Melioration (TIIM), 39 Kary Niyazov Street, Tashkent, 100000, Uzbekistan

${ }^{3}$ Université d'Orléans, CNRS/INSU Institut des Sciences de la Terre d'Orléans, UMR 6113 Campus Géosciences 1A, rue de la Férollerie 41071 Orléans, France

Contact author:

Dr. Frédéric HUNEAU, Université de Bordeaux, GHYMAC Géosciences Hydrosciences, UFR des Sciences de la Terre et de la Mer, B18 avenue des Facultés, 33405 Talence, France Tel : +33.5.40.00.88.41 ; fax: +33.5.40.00.31.13 ; frederic.huneau@u-bordeaux1.fr 


\begin{abstract}
The paper presents results of the application of a geostatistical approach to assess the water resources availability of the Akdarya reservoir in Uzbekistan. This geostatistical approach includes a (semi-) variogram analysis and interpolation (kriging and simulations -turning bands). Techniques predicting values at unsampled locations for generating digital bathymetric surface models of reservoir bottom conditions for calculating the volume and surface area at a given water elevation are also considered. The simulation enables to have a range of reservoir volumes and surface areas with the same probability in comparison to the kriging and traditional methods. The geostatistical approach creates digital surfaces that represent relatively accurate reservoir bottom conditions and support automated reservoir volumes and surface areas calculations. This in turn significantly reduces time, work load and financial burdens for sedimentation survey projects.
\end{abstract}

Keywords: water reservoir; sedimentation; bathymetric survey; geostatistics; volume estimation; Central Asia 


\section{Introduction}

\subsection{Sedimentation in water reservoirs}

Dam on a water course induces river fragmentation in both fluid and sediment fluxes. Though sedimentation is a natural geomorphologic process, human inference by dam construction accelerates the filling up of the reservoir capacity over time (Mahmood, 1987; WCD, 2000; ICOLD, 2005). The sedimentation causes reduction of the reservoir storage capacity and diminishes the flow regulation for water supply of different water users. The utility of a reservoir diminishes as its storage capacity is reduced (Bruk, 1985; WCD, 2000; IHP, 2002). As the stream flows, its sediment carrying capacity is diminished due to the decrease in flow velocity and increase in the cross-sectional area resulting in the sediments starting to deposit (McManus, 1985; Mahmood, 1987). The downstream movement of a stream's sediment load is then interrupted by reservoirs (Vörösmarty et al., 2003). Sedimentation triggers several important issues such as operation and maintenance of engineering facilities, economical feasibility of the project, environmental problems with social aspects upstream and downstream (Evrard, 1985; Brandt, 2000; Vörösmarty et al., 2003; Davis and Koop, 2006; Graf, 2006; Sternberg, 2006). It is reported that annually in the world an average $0.5-1 \%$ of the volume capacities of small and large reservoirs is lost because of sedimentation (Mahmood, 1987). Palmieri et al. (2001) report that the loss in volume capacity requires an annual replacement cost of US\$ 13 billion dollars. The reservoir sedimentation is a practical issue in many parts of the world with different climatic conditions and levels of engineering sophistication (Naisen and Lingyan, 1998; Krasa et al., 2005; Radoane and Radoane, 2005; Renwick et al., 2005).

\subsection{Reservoirs in Uzbekistan}

Agriculture is a very important sector for the Uzbek economy. It provides employment, foreign cash revenue and food security (O'Hara, 2000; Sokolov, 2006; Abdullaev et al., 2009). Climatic 
conditions and insufficient internal water resources have put pressure on water reservoirs. Uzbekistan is in fact largely an arid country where evaporation (1200-1600 mm) exceeds rainfall and annual precipitation is below $200 \mathrm{~mm}$ (Shultz, 1949; Irrigation of Uzbekistan, 1981; UNDP, 2007). Regional streamflow is characterized by an extreme intra-annual variability and is also unevenly spatially distributed (World Bank, 2003; Kazbekov et al., 2007). The two main transboundary rivers of Uzbekistan, the Amu Darya and Syr Darya, satisfy $82 \%$ of the total water demand of Uzbekistan, whereas only $18 \%$ of the demand is satisfied by the internal Kashka Darya, Zarafshan and Surkhan Darya rivers (Shultz, 1949; Heaven et al., 2002; Dukhovny, 2003; Micklin, 2004). At present approximately $90 \%$ of water resources in Uzbekistan are used for irrigated agriculture (UNDP, 2007; Rakhmatullaev et al., 2009) and about $24 \%$ of irrigation water comes from water reservoirs, the remaining being pumped from rivers and aquifers (FAO, 2007). The total number of man-made water reservoirs in Uzbekistan is 55 with a total volume capacity of about $19 \mathrm{~km}^{3}$ and a useful volume capacity of $14.5 \mathrm{~km}^{3}$ (Rakhmatullaev, 2006; UNDP, 2007). Nowadays there are almost no attractive sites for the construction of new reservoirs in Uzbekistan; as already said the Amu Darya is regulated by $78 \%$ and the Syr Darya by 94\% (Figure 1) (UNDP, 2007). Thus it is of strategic importance to rationally estimate the available water resources in existing reservoirs to ensure a guaranteed water supply to the different water users. In fact according to the Uzbekistan Ministry of Agriculture and Water Resources (UzMAWR), out of the 27 inspected reservoirs, 11 are almost completely silted up, and at 5 other reservoirs the silt has almost reached the level of the outlet structures (UNDP, 2007).

\subsection{Objectives}

The primary concern of this paper is a bathymetric survey of the Akdarya reservoir which was carried out to estimate the reservoir volume and surface area for corresponding reservoir stages (water elevations) in order to quantify the water availability (Ortt et al., 2000; USACE, 2001; 
IHO, 2005). Volume and surface area differences derived from multiple surveys of individual reservoirs then provide estimates of the capacity loss over time due to sedimentation. In Uzbekistan, bathymetric surveys were carried out with traditional methods such as range survey/end area method for the calculation of the reservoir volume and surface area for different reservoir stages. Traditional methods of analysis have relied on the topographic mapping and range survey data to estimate sediment volumes for a given reservoir.

The range survey/end area method has provided adequate results for past sedimentation analysis (USACE, 2001; IHO, 2005). However the ranges can be difficult to locate and surveys as monuments can be destroyed or worn away. This leads to the surveying of fewer ranges to characterize sedimentation. Two factors such as intensive field data measurement (depth soundings) and post data-processing often limit the frequency with which surveys may be conducted (Furnans and Austin, 2008).

There are many commercial computer contouring and surface mapping programs, which quickly and easily transform random surveying data into continuous curved face contours using interpolation. These computer technologies create digital surfaces that represent relatively accurate reservoir bottom conditions and support automated reservoir volumes and surface areas calculations. Automated reservoir volume calculation allows to quickly developing volumeelevation and surface-elevation curves for the estimation of sediment rates (Furnans and Austin, 2008). This in turn significantly reduces time, work load and financial burdens for sedimentation survey projects.

Geostatistical approach can be very helpful, reliable and efficient tools to increase the number of measurement points at unsampled places and variogram analysis for examining structural relationship of data for anisotropy analysis of a physical process that can have changed characteristics in the direction and space over traditional methods for bathymetric or topographic surveys (Joseph et al., 1998; Ortt et al., 2000; Marache et al., 2002; Soler-Lopez, 2003, 2004; Furnans and Austin, 2008). 
Digital contour surfaces of reservoir bathymetry are performed by two interpolation methods, the kriging and simulation (turning bands) techniques. In a first approach the kriging interpolation method is used to estimate the bathymetry. In a second part, because kriging provides a smooth result of the reality and has consequences for future computations (volume, area), the simulation method (turning bands) was chosen. One hundred simulations was carried out in order to introduce natural variability in the reservoir bathymetry and to get a statistical probability distribution of reservoir volumes and surface areas for different reservoir stages.

The final objective of the paper is a discussion of perspectives for the application of GIS (Geographic Information System), Google Earth ${ }^{\circledR}$ and DTM (Digital Terrain Model) methods for reservoir sedimentation studies that will be supplemental tools to predict the life span of the reservoir due to sedimentation and the choice of the discussed methodology for all bathymetric surveys in Uzbekistan.

\section{Study area and site characteristics}

\subsection{General setting}

The Akdarya reservoir was created by the construction of an earthen dam on the Akdarya River in 1982. This reservoir is used as a seasonal flood regulating structure for the irrigation of some 5,500 ha of new agricultural lands and to improve the conditions of more than 12,000 ha of irrigated lands in two districts of the Samarkand province of Uzbekistan (Figure 1). It is located $15 \mathrm{~km}$ northwest of the Ishtihan town. The surface area of the reservoir at full pool elevation (FPE) is about $12.7 \mathrm{~km}^{2}$, the total storage volume is $112.5 \mathrm{Mm}^{3}$. In order to increase the irrigated lands, authorities have increased the reservoir volume capacity from 34 to $112.5 \mathrm{Mm}^{3}$ by raising the dam crest by $7 \mathrm{~m}$ since 1982 (Samarkandgiprovodhoz, 1976).

\subsection{Relief and geomorphology}


The modern Akdarya River valley is in-filled with pro-alluvium deposits. The valley is layered by loess and loams with 5-40 m thickness, underlying a layer of gravel with a thickness of about $300 \mathrm{~m}$. The modern floodplain part of the Akdarya River is composed of loams, stones and pebbles of alluvial origin. The thickness of modern deposits varies from 0.5 to $5 \mathrm{~m}$ (Rakhmatullaev, 2007). The river channel is well defined, composed of pebble-cobble deposits. The absolute elevation of the river varies from $680 \mathrm{~m}$ to $400 \mathrm{~m}$ above the sea level. On the right bank, the relief of surrounding areas is presented by the hills with smooth peaks changing into alluvial and pro-alluvial uplands. The left bank is composed of floodplains and terrace valleys (Uzdavsuvloixa, 2002).

\subsection{Climate}

The study area is located in the subtropical latitudes of the centre of the Asiatic continent and it is characterized by aridity and significant temperature fluctuations. The mountain system of Nurata in the north governs local climatic conditions, such as precipitation and wind regimes. The main meteorological characteristics are presented in Table 2. The annual long-term mean precipitation is about $282 \mathrm{~mm}$. More than $90 \%$ of annual precipitation is observed from November to May. Over the period of June-September, there is no precipitation observed. The mean evaporation from the reservoir is about $1200 \mathrm{~mm}$ inducing a deficit balance about $918 \mathrm{~mm}$ annually (Uzdavsuvloixa, 2002; Rakhmatullaev and Le Coustumer, 2006).

\subsection{Hydrological characteristics}

The Akdarya River is a tributary of the Zarafshan River (Figure 1). The Zarafshan River is divided into tributaries at the Ak Karadarya Hydraulic Scheme. East of the Samarkand city, the Zarafshan is separated into two perennial tributaries, a northern one (Akdarya) and a southern one (Karadarya). These two tributaries form an island with a total length of about $100 \mathrm{~km}$ and about $15 \mathrm{~km}$ in the width under the name "Miankul". The two tributaries again merge into one 
Zarafshan River in Navoi province. The Akdarya reservoir is located on the Akdarya River 50 km downstream from Ak Karadarya Hydraulic Scheme. The total length of the Akdarya River is about $131 \mathrm{~km}$ and it flows over wide floodplain terraces with a width of about $0.2-0.6 \mathrm{~km}$ and with a maximum width of about $1.5-2.0 \mathrm{~km}$. The river channel is moderately meandering and branching. River banks are unstable and steep in some places. The Akdarya River flows through the Zarafshan Valley, which is composed of loess deposits (Samarkandgiprovodhoz, 1976).

There are several kinds of water resources feeding the Akdarya reservoir (Table 3). The network of regional irrigation channels and drainage-collector discharge systems are a source of water directly feeding the reservoir. Traditional engineering practices have evolved in such direction that only during high-water years waters of Zarafshan River are released to the Akdarya River. The last significant discharge was observed in 1998 (Uzdavsuvloixa, 2002). This release discharge was about $100 \mathrm{~m}^{3} / \mathrm{s}$. At present time, the Akdarya tributary is used as an emergency channel from catastrophic flooding events of the Zarafshan River, whereas the main flow passes through the Karadarya tributary.

The springs and temporary streams are the third major source of water feeding the Akdarya River and its reservoir. The temporary streams can be observed during heavy rainstorms during the spring season. The effective watershed area of the Akdarya reservoir is about $2020 \mathrm{~km}^{2}$ (Uzdavsuvloixa, 2002). Figure 2 depicts the water and suspended sediment discharge in a year. The peak of sediment discharge is observed during the flood of the Akdarya River. As the Akdarya River is used as an artificial catastrophic channel for conveying excess water of the Zarafshan River, the streamflow entrains the most of available sediment and discharges downstream. The dry climatic and geomorphological conditions contribute to rising limb of sediment discharge curve i.e. most available sediment loads can be carried out by the Akdarya River in the event of high floods.

\section{Material and method}


In 2001 the "Uzbek Bathymetric Centre" was established under the umbrella of UzMAWR and was authorized to survey the reservoirs using the bathymetric investigation system (CEEDUCER $\left.{ }^{\circledR}\right)$ developed by Bruttour International Pty Ltd (Bruttour, 2003). This system is composed of an incorporated GPS (Global Positioning System) antenna and a digital depth measuring transducer. Up to now, the centre has performed bathymetric surveys of 16 reservoirs in Uzbekistan (Bathymetric Centre, 2003). Figure 3 illustrates the loss of the total and dead reservoir volume capacities in 16 reservoirs in Uzbekistan due to sedimentation. The dead volume storage in a reservoir is determined as the storage volume between the stream bed and the lowest elevation from which water can be withdrawn by gravity (Mahmood, 1987). As it can be seen, the total volume capacities of all reservoirs have decreased by about $18 \%$, whereas the dead storage capacities decreased by $55 \%$ on the average. In comparison, the dead storage capacities of 7 Uzbek reservoirs were decreased by more than $75 \%$. This is an alarming signal that in a foreseen future the sedimentation can be a major operation and maintenance issue for these reservoirs and threatens the guaranteed water supply to water users.

\subsection{Bathymetric survey}

The bathymetric survey of Akdarya reservoir was conducted in 2003 from a moving boat using electronic depth-sounding equipment (transducer) in conjunction with a GPS antenna and an automatic data recorder CEEDUCER ${ }^{\circledR}$. All data recorded were transferred into a laptop computer (Joseph et al., 1998; Ortt et al., 2000; Soler-Lopez, 2003 and 2004). The system CEEDUCER ${ }^{\circledR}$ is a very small, single unit (integrated GPS receiver, electronics processor and data logger), versatile survey measuring instrument that provides: GPS position, DGPS (differential GPS), digital echo sounder and 7.2 hour full data logging (dual frequency echo sounding). The specifications of the GPS receiver are as follows: survey type 8 or 12 channels (true parallel) with an accuracy of 2-3 m (8 channels) and lower than $1 \mathrm{~m}$ (12 channels). DGPS combined Marine Beacon/Integrated GPS antenna with 1 second update. 
The GPS receivers monitor the horizontal position of the survey boat while the depth sounder measures the water depth. The GPS units were first used and by default were automatically converted into a WGS84 (World Geodetic System of 1984) projection system in the static mode to establish a benchmark overlooking the reservoir. Satellite data were recorded simultaneously at the known government geodesic benchmark (referred to as "the Akdarya dam") (latitude $27^{\circ} 45^{\prime} \mathrm{N}$., longitude $44^{\circ} 33^{\prime} \mathrm{W}$.) and at a site overlooking the reservoir. Once established, the “Akdarya dam" benchmark was programmed as the reference station.

One GPS unit was installed at the reference station; the other GPS unit was installed in the survey boat to be used as a mobile station. The GPS on board independently calculated a position every second, while receiving a set of correction signals from the reference station, converting the system into a DGPS. This combination maintained the data horizontal position accuracy within a tolerance of two meters. The bathymetric survey integrated software MiniCee ${ }^{\circledR}$ and was used to navigate and to collect data. The software integrates the depth and position data, storing the $\mathrm{x}, \mathrm{y}$ (geographic locations) and $\mathrm{z}$ (depths) coordinates in a portable computer.

GPS was used to determine the latitude and longitude for each depth measurement. Sounding equipment was used to measure depth from a transducer (probe), operating at a frequency of 200 $\mathrm{kHz}$ to the bed of the reservoir. Depths recorded by the sounder, which has a resolution of $0.02 \%$, were measured at a fixed distance below the water surface (Bathymetric Center, 2003). The recorded depths and the constant value of the depth ecosounder were subtracted from the water surface elevations at the time of the survey (as recorded at the dam gauge) to determine reservoir bottom elevations. The depths were synchronized with the GPS data to determine the location of the probe as the boat traversed across the reservoir (IHO, 2005; Furnans and Austin, 2008). The schematic illustration of the depth sounding survey and conditions in the Akdarya reservoir for 2003 is depicted in Figure 4. The calibration of the transducer was performed twice daily, before and after the measurements collection. 
For the shallow water areas where the transducer could not be operated, representative depth measures were manually collected with a stadia rod from the boat. However sediment accumulation and vegetation growth in the upstream reservoir areas limited the data collection. The shoreline delineation was performed during the survey by GPS receiver as close as possible to water surface marks along the reservoir shoreline.

Initial editing of the data was performed using the MiniCee ${ }^{\circledR}$ software. Positions were corrected to eliminate anomalies that occurred when the correction signal from the reference station was lost because of local topographic features or electromagnetic interference. Position errors were corrected by interpolating back to the mid-point between the correct antecedent and preceding position. The depth data were also corrected to eliminate incorrect depth readings. Incorrect depth readings can result from an insufficient signal gain or because floating debris or fish interfered with the transducer face. The incorrect depth readings were also interpolated between the correct antecedent or precedent depth readings. Once corrected, the edited data were transferred into the Golden Software's SURFER ${ }^{\circ} 7$ database for further processing.

\subsection{Geostatistical analysis, variogram analysis}

With recent progresses in automatic calculations, the use of geostatistics for the spatial analysis of environmental data has become extremely common both on land and sea (Mear et al., 2006). Geostatistics include tools that establish surface maps of any interested variable from the analysis of the spatial structure of data (semivariogram) and to predict the value (interpolation) of these parameters at unsampled points (kriging or simulation) (Chilès and Delfiner, 1999; Goovaerts, 1999).

Variogram analysis was used to examine the spatial or temporal correlations of the data. Variogram analysis is a prerequisite for interpolation (kriging or simulation) or making predictions (Clark, 2001; Mear et al., 2006). Variogram analysis consists of the experimental variogram calculated from the data and the theoretical model fitted to the data. The experimental 
variogram measures the mean variability between two points $z$ and $z+\mathrm{h}$, as a function of their distance $h$.

The experimental semi-variogram is calculated by the following equation:

$$
\hat{\gamma}(\mathrm{h})=\frac{1}{2 \mathrm{~N}_{\mathrm{h}}} \sum_{\mathrm{x}_{\mathrm{j}}-\mathrm{x}_{\mathrm{i}} \approx \mathrm{h}}\left[\mathrm{z}\left(\mathrm{x}_{\mathrm{j}}\right)-\mathrm{z}\left(\mathrm{x}_{\mathrm{i}}\right)\right]^{2}
$$

where $\gamma(h)$ is the experimental semi-variogram taking into account the difference in value between pairs of samples with a given relative orientation and distance apart $(h)$ between two measured attributes, $h$ is the distance between two discrete points that are used for variogram calculation, $n$ is the number of pairs of samples for a given $h, z$ is the investigating attribute, $i$ and $j$ are the indexes of respective values of two samples apart of the distance $h$.

The experimental variogram is calculated for several lag distances and is plotted as a twodimensional graph $\gamma(h)=f(h)$. It is then fitted with a theoretical model which provides information about the structure of the spatial variation, as well as the input parameters for spatial prediction by kriging (Saby et al., 2006).

In a first approach we chose to use kriging, because it is the estimation method minimizing the best interpolation errors and allowing the calculation of variance associated with the interpolation. Kriging calculates a weighted moving average equation which estimates the value of a regionalized variable at site specific location by taking into account the variographical information. The optimum grid size for the construction of the bathymetric surfaces was determined based on examination of the sampling distribution for the three periods. The kriging interpolation gives the averaged smoothed surface and thus will underestimate the realistic reservoir volume and surface area calculation.

Therefore for the introduction of natural variability we used as a second approach turning bands interpolation method for simulation. One hundred simulations calculations were performed using the ISATIS ${ }^{\circledR}$ program (Geovariances, 2009). Post-processing of simulations allows to obtain a statistical distribution of reservoir volume and surface area. 


\section{Results and discussion}

\subsection{Historical surveys}

For the determination of sedimentation rates three bathymetric surveys, the original (preimpoundment) in 1982 and the 1996 and 2003 ones were used to examine the evolution of the reservoir capacity over time. The 1982 and 1996 surveys were carried out by traditional methods, such as range survey/end area method and traditional measuring instrumentation. The

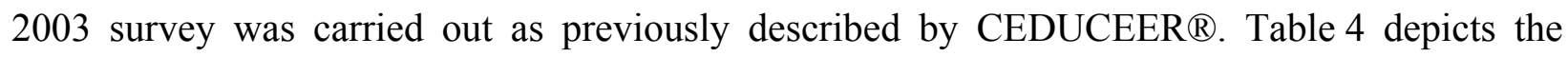
volumes, water surface areas at full and minimum pool elevations of the Akdarya reservoir for three historical surveys. The analysis of sedimentation dynamics was performed for two periods: 1982-1996 and 1996-2003. The changes in volume and water area at FPE and minimum pool elevation (MPE) were examined.

For the 1982-1996 period, the total sedimentation volume was $11.8 \mathrm{Mm}^{3}$ which can be interpreted as the total reservoir volume decreased by $10.5 \%$, the water area decreased by $8 \%$ and the dead storage decreased by $12 \%$ at FPE. However, these changes differ for the reservoir at MPE, for instance the water area decreased by $53 \%$ to the original. This is caused by the reservoir's morphological shape and its location in lowlands (plains).

For the period of 1996-2003, the total sedimentation was $7.5 \mathrm{Mm}^{3}$ and the total reservoir volume decreased by $7.5 \%$ compared to the 1996 level. On the other hand, the water area increased by $2.3 \mathrm{~km}^{2}(16.5 \%)$ due to significant right bank collapses, in some places reaching $10-50 \mathrm{~m}$ in width (Figure 4). The dead storage decreased by $0.74 \mathrm{Mm}^{3}(34 \%)$ at the FPE in Akdarya reservoir. At the MPE, the water area of reservoir decreased by $44 \%$.

The volume storage capacity loss rate is a key component for calculating the remaining life of a reservoir (Ortt et al., 2000). Using the volumes of accumulated sediment and the age of the reservoirs, the annual storage capacity loss rates can be calculated. During the 21 years of 
reservoir operation, the total loss of reservoir capacity due to sediments is estimated to be about 19.3 $\mathrm{Mm}^{3}$. The Akdarya reservoir has lost its storage capacity at a rate of $0.92 \mathrm{Mm}^{3}$ per year. As a percentage of its original storage volume, the annual loss rate for Akdarya reservoir is $0.8 \%$ up to 2003. The high rate of loss is explained by the significant right-bank erosion processes in some places reaching 20-50 m collapses and local geomorphological conditions with high sediment amounts coming from surrounding agricultural lands.

The maximum depth according to the design calculations was $23.4 \mathrm{~m}$, but the deepest depth observed during the last survey was recorded at $18.1 \mathrm{~m}$. During the field survey, the area of shallow water increased, especially in the entrance part of the river where nowadays the upstream of the reservoir is also heavily occupied by the vegetation cover and in some places locals have created artificial rice paddy plots, the area with such plantations is always increasing (Figure 1 and 4).

\subsection{Data measurement}

The depth soundings were collected every $20 \mathrm{~m}$. The transects (cross-sections) were about $200 \mathrm{~m}$ apart beginning at the dam and continuing upstream. Figure 5 illustrates the 2003 depth sounding measurements across 35 sections in Akdarya reservoir. The transects were perpendicular to the shoreline of the reservoir. The process of obtaining an accurate bathymetric survey is substantially more difficult than that associated with land-based surveying. There are various error sources in data acquisition and measurement in bathymetric survey such as GPS limited availability, the definition of the water-mud interface and human errors in measurements (IHO, 1998 and 2005; USACE, 2001).

Furnans and Austin (2008) report that original reservoir volume estimates are limited by the accuracy of existing topographic maps and land surveys estimates of the current capacities for reservoirs not re-surveyed since their construction. The range method is based upon interpolating the volumes from one range transect to another. The further apart the transects, the more 
interpolation is involved and intuitively more errors can be observed (Byrnes et al., 2002; Johnston, 2003). For example, there can be local topographic or other peculiarities, such as water intake structures or significant dredge works in area between transects. The complication can be of natural river inflow areas. The total error in determining reservoir capacity volumes through the use of this method have been estimated to be between 10 and 30\% (Ortt et al., 2000).

With traditional methods of depth measurements and few sampled points, large errors and uncertainties are observed that increases errors in computation of water availability in water reservoirs. The potential sources of error are (i) human induced during data measurement in the boat operation and (ii) readings of the transducer (e.g. penetration of sonar signal through the water column and poor acoustic reflection of signal back from true reservoir bottom surface) (IHO, 1998).

\subsection{Geostatistical work Variographical analysis}

First, the experimental semivariogram was calculated and constructed from the direct field measurements. In order to look for possible directions of anisotropy (difference in spatial structuration of the variable as a function of the studied direction), directional variograms were computed every $10^{\circ}$ and with a $200 \mathrm{~m}$ lag. In our case the directional variograms showed an anisotropy whose both principal directions were N20 and N110. Figure 6 depicts the semivariogram of reservoir bottom elevations for the Akdarya reservoir. For a given lag, the smallest variogram values were observed in the N110 direction and the largest values in the N20

direction. Furthermore the variogram showed a stationnarity for N20 (with a sill equal to $9 \mathrm{~m}^{2}$ for a range of $800 \mathrm{~m}$, distance beyond which there is no correlation between data) and a nonstationary behaviour for N110. A variable is stationary if its statistical distribution is invariant by translation in space (and its moments too). On a variogram, we can check that a variable is stationary (at least a second order stationnarity) if we can observe a sill, as in the N20 direction 
in our case. For a non-stationary behaviour (as in the N110 direction), the variogram doesn't reach a sill, indicating a global drift in data (for example a constant increase of values in this direction).

Secondly, the theoretical model was fitted with a spherical model and the anisotropy was defined as the ratio between the largest and the smallest variance (Figure 6, dotted charts). The fitting was the best for $h$ less than $1000 \mathrm{~m}$, because of neighbourhood problems, which is addressed by the kriging.

\section{Kriging results}

After the variogram analysis, the interpolation was carried out using a kriging gridding method. In order to estimate a value at a non-sampled point, we considered measured points in a given neighbourhood. The chosen neighbourhood was an ellipse with axes equal to $1000 \mathrm{~m}$ and $500 \mathrm{~m}$ in N110 and N20 directions, respectively. The ellipse was then decomposed in 4 sectors and we chose to have an optimum number of data equal to 10 in each sector. The Figure 7 illustrates the bathymetry of Akdarya reservoir by kriging interpolation method.

There is no significant difference between the elevation-reservoir volume and the elevationsurface area curves from direct measurements and modelled (kriging). The Figure 8 depicts the reservoir volume and the surface area by kriging and the direct measurements data (2003) for selected water elevations, where the significant differences were observed. The computation of the reservoir volume and surface area by kriging was performed by reducing the number of actual cross-sections from 35 to 17 . In particular, we reduced the cross-sections in the middle parts of reservoir due to smooth uniform bed conditions observed from field measurements. This shows that fewer depth soundings, but representative points can be measured regardless of using any surface contouring packages used. Figure 9 depicts the reservoir volume of Akdarya at different water elevations. The 2-D bathymetric map has visualization effect for a reservoir operator who can use this information in decision making over operation and maintenance 
works. This is particularly important for the water intake structures that are installed in a reservoir for irrigation diversions or public water supply systems. Operators could take site specific preventive measures to alleviate for such scenarios.

The principal source of error that is reflected within the dataset is related to the density and the spatial configuration of the sample points (Johnston, 2003). The spatial configuration is critical in the kriging process and in all interpolation methods. The kriging weights and the variance of estimation are dependent of the variogram, and the spatial distribution of the points but not of the measured values. This is why equidistant spacing would be the best in bathymetric data collection. Spacing of data points was much greater between transects than between points on a given transect. Such a sampling approach introduces necessarily larger variances (so error) between transects into the modelled bathymetric surface. Because kriging minimizes the variance of estimation (it gives a smooth image of the reality and only an estimation of volume and area) simulation methods have been carried out.

\section{Simulation results}

After the kriging interpolation, 100 simulations (turning bands) were carried out to compile bathymetric surface models of reservoir bottom, in order to calculate reservoir volume and surface areas. Simulations allow to introduce variability and to obtain a statistical distribution of reservoir volume and area for any water level. The results are given in Table 5 and Figure 10. Generally, for water elevations, the kriging and direct measurement calculations fall within the range of minimum and maximum values of simulation. In particular, the significant difference in reservoir volume is observed at higher water elevations due to the morphological shape of the Akdarya reservoir. At a $494.5 \mathrm{~m}$ water elevation, there is a difference of about $2 \%$ between the simulated maximum reservoir volume $\left(94.47 \mathrm{Mm}^{3}\right)$ and the measured one $\left(93.17 \mathrm{Mm}^{3}\right)$, that corresponds to $1.3 \mathrm{Mm}^{3}$ of water. The Figure 11 shows the cumulative distributions of the reservoir volume and area for a water elevation equal to $494.5 \mathrm{~m}$. 


\subsection{Economical efficiency results}

New contour and mapping programs have introduced automated reservoir volume and surface calculations. This has significantly reduced the time, workload and financial burdens of such projects. This is real financial savings for the introduction of geostatistical approach in reservoir sedimentation projects in conditions of Uzbekistan. For example, the economic efficiency for calculation of $1 \mathrm{~km}^{2}$ of reservoir decreased from 570 (conventional method) to 385 \$US (geostatistical method). The savings per $1 \mathrm{~km}^{2}$ is about $155 \mathrm{US} \$$. The largest savings is obtained from the reduction of the field work and post-data analysis by $50 \%$. The most important aspect in the geostatistical approach is the increase of the calculated area of the bathymetry with a decreased number of transects. It must be pointed out that this method of simulation and estimation of reservoir volume and surface area refers to the assessment of the total volume of trapped sediments in the reservoir. However, the spatial distribution of the deposited sediment volume has profound significations for the sedimentation countermeasure plan. The location of the deposited sediment within the reservoir may be of equal or even greater importance to the reservoir operations, as is the total volume deposited (Mahmood, 1987).

\subsection{Perspectives in Uzbekistan}

The USACE has started to apply a new DTM method for the sedimentation analysis and the calculation of reservoir volumes and surface areas in 2000 (Smith, 2000). The DTM method relies on the digital conversion of historical topographic mapping and the collection of the recent sounding survey data for the creation of digital surface models of reservoir bottoms. The DTM method calculates sediment volumes over the entire reservoir area by comparing historical topography and recent sounding data digital surfaces. Topographic mapping of the site prior to the inundation represents the original reservoir bottom conditions. These topographic maps are digitized and geo-referenced to produce the contour coverage. Contour data are processed in a 
GIS software package. GIS has being used for the reservoir sedimentation in recent surveys elsewhere (Sawunyama et al., 2006). The final calculations for the sediment volumes are determined by subtracting the original reservoir capacity from the recent resurveyed capacity. Water and sediment depth models are created as a result. The water depths are calculated by subtracting the resurveyed DTM from the seasonal pool elevation, sediment depths are calculated by subtracting the original surface from the resurveyed one. The sediment depth grid provides a tool for the visualization of the spatial sediment distribution over the reservoir. This greatly enhances the illustration of the sediment accumulation for the operators and the water managers, and enables them to locate intensive sediment accumulation areas. Consequently, it will be a real asset for mitigation measures to be undertaken.

In addition, the Google Earth ${ }^{\circledR}$ program can be incorporated into the reservoir sedimentation studies as a supplemental analysis instrument for various periods of re-surveying, which will enable both researchers and dam operators to see the changes in the concerned area.

Recent research indicates that sediment yield from watersheds should be incorporated into the reservoir sedimentation studies. The new paradigm for such initiatives can be the Integrated Sediment Management programs that are advocated around the world (SedNet, 2004). The integrated reservoir sedimentation studies would improve decision making process for choosing the appropriate preventive measures, such as hydraulic flushing, sluicing, and hydraulic or mechanical dry dredging operations. This in turn can decrease the overall financial expenses for mitigation actions. For example, according to UzMAWR the rivers of Uzbekistan Amu Darya, Syr Darya and Zarafshan transport about $80-85 \%$ of the total annual sediment yield during the peak flows. Thus, on time operational modes of reservoirs maintenance can substantially reduce sediment accumulation in the reservoirs by hydraulic flushing and manoeuvring sluice gates.

\section{Conclusion}


The reservoir sedimentation surveys were carried out with traditional range survey/end area method over the years. Since 2003 reservoir sedimentation surveys have been conducted with new bathymetric system that incorporates GPS and electronic transducer capabilities. However, manual data management persists in the practice, which is tedious and costly with large human induced errors for calculation of reservoir volume. The proposed geostatistical method has shown its cost-effectiveness for bathymetric surveys in Uzbekistan.

Geostatistical approach has many advantages compared to the traditional computation methods with statistical analysis of data variance and known fitting mathematical model for interpolation. Kriging interpolation method is a good first approximation. Simulation (turning bands) interpolation introduces range of volumes and surface areas in contrast to traditional estimates. Range volume values are more realistic estimates and provide water managers and dam operators with information about possible minimum and maximum estimates. In turn, it is believed that there would be possibilities to react appropriately in the decision making process. Presently, only single volume curves are used for the assessment of reservoir sedimentation in Uzbekistan. Geostatistical approach reduces the workload for post-data processing and has shown its economic efficiency for reservoir sedimentation projects and improves digital database for a given reservoir and future computations of reservoir volume evolution.

New methods, such as DTM methods and application of GIS capabilities must be incorporated in reservoir sedimentation projects for studying not only the total volume of sedimentation, but the spatial distribution of sediment accumulation in the reservoir. This DTM method provides reservoir operators with a better visualization of sedimentation processes and thus enables them to launch mitigation measures on a timely manner.

With the application of GIS and computer surface mapping software technologies, the new data management schemes at the national scale can be envisioned with the creation of digital maps of reservoirs for sustainable operation of Uzbekistan environment and physical infrastructure for the coming years. 


\section{Acknowledgement}

The authors would like to thank the French Embassy in Tashkent for supporting the French-Uzbek cooperation in the field of water sciences. This study has also been supported by INTAS fellowship Nr. 04-83-3665 and by the French Ministry of Foreign Affairs via the Eiffel fellowship program No. 530909C. Special acknowledgements are expressed to the Bathymetric Centre of Uzbekistan, Ministry of Agriculture and Water Resources. However, the views expressed in this paper do not necessarily reflect those of the funding agencies, and no official endorsement should be inferred from it. 


\section{References}

Abdullaev I, De Fraiture Ch, Giordano M, Yakubov M, Rasulov A. 2009. Agricultural water use and trade in Uzbekistan: Situation and potential impacts of market liberalization. Water Resources Development 25(1): 47-63.

Bathymetric Center. 2003. Estimation of Ak Darya reservoir capacity using CEEDUCER (in Uzbek). Technical report. Uzbekistan Ministry of Agriculture and Water Resources, Tashkent, Uzbekistan. 20pp.

Brandt SA. 2000. Classification of geomorphological effects downstream of dams. Catena, 40: $375-401$.

Bruk S. 1985. Prediction methods. In: Methods of computing sedimentation in lakes and reservoirs, Bruk S (ed). International Hydrological Programme, IHP-II Project, A.2.6.1.Panel, UNESCO, February, Paris; 165-210.

Bruttour International Pty.Ltd. 2003. CEEDUCER. User guide Ceeducer1 operation and download. Australia. 96p.

Byrnes MR, Baker JL, Li F. 2002. Quantifying potential measurement errors and uncertainties associated with bathymetric change analysis. Coastal and Hydraulics Engineering Technical Note. U.S. Army Corps of Engineers. ERDC/CHL CHETN-IV-50, September.17pp. http://cirp.wes.army.mil/cirp/cirp.html

Chilès JP., Delfiner P. 1999. Geostatistics - Modeling spatial uncertainty. Wiley Interscience Publication. 695p.

Clark I. 2001. Practical Geostatistics. Central Scotland. 119p.

Davis RJ, Koop K. 2006. Eutrophication in Australian rivers, reservoirs and estuaries- a southern hemisphere perspective on the science and its implications. Hydrobiologia 559: 23-76.

Dukhovny VA. 2003. The Aral Sea Basin - Rumors, realities, prospects. Irrig. and Drain. 52: 109-120. DOI:10.1002/ird.85. 
Evrard J. 1985 Technical and economic impact of reservoir sedimentation. In: Methods of computing sedimentation in lakes and reservoirs, Bruk S (ed). International Hydrological Programme, IHP-II Project, A.2.6.1.Panel, UNESCO, February, Paris; 110.

FAO (Food and Agriculture Organization of United Nations) 2007. http://www.fao.org Accessed on 15 November of 2007.

Furnans J, Austin B. 2008. Hydrographic survey methods for determining reservoir volume. Environmental Modeling\&Software 23: 139-146. DOI 10.1016/j.envsoft.2007.05.011.

Geovariances. 2009. Isatis v9 software manual.

Goovaerts P. 1999. Geostatistics in soil science: state-of-the-art and perspectives. Geoderma 89: $1-45$.

Graf WL. 2006. Downstream hydrologic and geomorphic effects of large dams on American rivers. Geomorphology 79: 336-360.

Haan CT, Barfield BJ, Hayes JC. 1994. Design hydrology and sedimentology for small catchments. Academic Press. San Diego, California. 588p.

Heaven S, Koloskov GB, Lock AC, Tanton TW. 2002. Water resources management in the Aral Basin: a river basin management model for the Syr Darya. Irrig. and Drain. 51: 109118.

ICOLD (International Commission on Large Dams) 2005. http://www.icold-cigb.org. The site was accessed on 15 June, 2005.

IHO (International Hydrographic Organization) 1998. IHO Standards for Hydrographic Surveys. Special Publication No.44, $4^{\text {th }}$ Edn., Monaco. 23p.

IHO (International Hydrographic Organization) 2005. Manual on Hydrography. Publ. No. M-13. $1^{\text {st }}$ Ed. Monaco, http://www.iho.shom.fr May. 
IHP (International Hydrological Programme) 2002. Modeling erosion, sediment transport and sediment yield. Ed. Summer W. and Walling D.E. IHP-VI, Tech. Docs in Hydrology, No.60, UNESCO, Paris. 264p.

Irrigation of Uzbekistan 1981. Technological progress in Irrigation. Volume IV. Fan, Tashkent, Uzbekistan. 445p.

Johnston Sh. 2003. Uncertainty in bathymetric surveys. Coastal and Hydraulics Engineering Technical Note. U.S. Army Corps of Engineers. ERDC/CHL Coastal Hydraulics Engineering Technical Note-IV-59. March. 22p.

Joseph A, Bernert JA, Sullivan TJ. 1998. Bathymetric analysis of Tillamook Bay: Comparison among bathymetric databases collected in 1867, 1957 and 1995. March. E\&S Environmental Chemistry, Inc.Corvallis, OR. 23p.

Kazbekov J, Rakhmatullaev S, Huneau F, Le Coustumer P 2007. Types and hydrogeologic features of surface and groundwater interactions in Uzbekistan. 35th International Association of Hydrogeologists Congress, Lisbon, Portugal, 17-21 September 2007. Conference Proceedings, ISBN978-989-95297-3-1.

Krasa J, Dostal T, Van Rompaey A, Vaska J, Vrana K. 2005. Reservoirs' siltation measurements and sediment transport assessment in the Czech Republic, the Vrchlice catchment study. Catena 64: 348-362.

Mahmood K. 1987. Reservoir sedimentation. Impact, extent and mitigation. WTP No.71, ISBN 0-8213-0952-8. World Bank, Washington, D.C. 118p.

Marache A., Riss J. Gentier S., Chilès JP. 2002. Characterisation and reconstruction of a rock fracture surface by geostatistics. International Journal for Numerical and Analytical Methods in Geomechanics 26(9): 873-896.

McManus J. 1985. Physical processes of reservoir sedimentation. In: Methods of computing sedimentation in lakes and reservoirs, Bruk S (ed). International Hydrological Programme, IHP-II Project, A.2.6.1.Panel, UNESCO, Paris; 11-40. 
Mear Y, Poizot E, Murat A, Lesueur P, Thomas M. 2006. Fine-grained sediment spatial distribution on the basis of a geostatistical analysis: Example of the eastern Bay of the Seine (France). Continental Shelf Research 26: 2335-2351.

Micklin Ph. 2004. The Aral Sea crisis. In: Dying and dead seas-Climatic versus anthropic causes, Nihoul J, Zavialov P, Micklin Ph (Eds). Kluwer Academic Publishers, Netherlands; 49-76.

Naisen J, Lingyan F. 1998. Problems of reservoir sedimentation in China. Chinese Geographical Science 8(2): 117-125.

O'Hara SL. 2000. Lessons from the past: water management in Central Asia. Water Policy 2: $365-384$.

Ortt RAJr., Kerhin RT, Wells D, Cornwell J. 2000. Bathymetric survey and sedimentation analysis of Loch Raven and Prettyboy reservoirs. Maryland Geological Survey. Coastal and Estuarine Geology File Report No. 99-4. September. 56p.

Palmieri A, Shah F, Dinar A. 2001. Economics of reservoir sedimentation and sustainable management of dams. Journal of Environmental Management 61: 149-163.

Radoane M, Radoane N. 2005. Dams, sediment sources and reservoir silting in Romania. Geomorphology 71: 112-125.

Rakhmatullaev S. 2006. Geoinformation systems for estimation of reservoir volume capacities due to sedimentation (in Russian). Final Proc. IV Conf. Specialist who studied abroad. Uzbekistan President Foundation ISTEDOD, Vol.XI, Tashkent, Uzbekistan, November $24-25,40-51$.

Rakhmatullaev S, Le Coustumer Ph. 2006. Sedimentation dynamics of Ak Darya reservoir. Final Proc. National Conf. Complementary hydraulic structures safety assurance, Tashkent Institute of Irrigation and Melioration, Tashkent, Uzbekistan, 22-23 November 2006, pp.38-40. 
Rakhmatullaev S. 2007. Some aspects of SURFER software use in sedimentation estimation of reservoir (in Russian). Journal of Tashkent Technological State University Vestnik TashGTU, 1/2007: 165-168.

Rakhmatullaev S., Huneau F., Kazbekov J., Le Coustumer P., Jumanov J., El Oifi B., MotelicaHeino M., Hrkal Z. 2009. Groundwater resources and management in the Amu Darya River Basin (Central Asia). Environmental Earth Sciences, 59, 1183-1193. DOI:10.1007/s12665-009-0107-4

Renwick WH, Smith SV, Bartley JD, Buddemeier RW. 2005. The role of impoundments in the sediment budget of the conterminous United States. Geomorphology 71: 99-111.

Saby N, Arrouays D, Boulonne L, Jolivet C, Pochot A. 2006. Geostatistical assessment of Pb in soil around Paris, France. Science of the Total Environment, 367: 212-221. DOI:10.1016/j.scitotenv.2005.11.028

Samarkandgiprovodxoz (Samarkand hydrological design institute) 1976. Feasibility study of dam construction on Ak Darya river, Kattakurgan district, Samarkand province (in Russian). Hydrological report, 81p.

Sawunyama T, Senzanje A, Mhizha A. 2006. Estimation of small reservoir storage capacities in Limpopo River Basin using geographical information systems (GIS) and remotely sensed surface areas: Case of Mzingwane catchment. Physics and Chemistry of the Earth 31: 935-943.

SedNet (the European Sediment Research Network). 2004. Contaminated Sediments in European River Basins. Final Report. http://www.SedNet.org .-46p

Shultz VL. 1949. Central Asian rivers. Nauka, Moscow. 195p.

Smith SL. 2000. Application of Geographical Information System in data analysis and presentation for sedimentation studies. $6 \mathrm{p}$.

Sokolov V. 2006. Experiences in IWRM in the Central Asia and Caucasus Region. Water International 31(1): 59-70. 
Soler-Lopez LR. 2003. Sedimentation History of Lago Guayabal, Puerto Rico, 1913-2001. U.S. Geological Survey Water-Resources Investigations Report 03-4198. 28p.

Soler-Lopez LR. 2004. Sedimentation survey of Lago Toa Vaca, Puerto Rico, June-July 2002. U.S. Geological Survey Scientific Investigations Report No. 2004-5035. 32p.

Sternberg R. 2006. Damming the river: a changing perspective on altering nature. Renewable and Sustainable Energy Reviews 10: 165-197.

UNDP (United Nations Development Programme) 2007. Water, critical resource for Uzbekistan's future. UNDP Program, Tashkent, Uzbekistan, 121p.

USACE (United States Army Corps of Engineers) 2001. Hydrographic Surveying Engineering manual. Engineering and Design. No. 1110-2-1003. Washington DC. January.

Uzdavsuvloiha (Uzbekistan state water design institute) 2002. Estimation of hydrological characteristics of Ak Darya reservoir in Samarkand province (in Russian). Technical report. Tashkent, Uzbekistan, 30p.

Vörösmarty C.J, Meybeck M, Fekete B, Sharmad K, Green P, Syvitski JMP. 2003. Anthropogenic sediment retention: major global impact from registered river impoundments. Global and Planetary Change 39: 169-190.

WCD (World Commission on Dams) 2000. Dams and Development: A New Framework for Decision-Making. Earthscan Publ. ISBN 1-85383-797-0.

World Bank. 2003. Irrigation in Central Asia: Social, economic and environmental considerations. www.worldbank.org/eca/environment. Accessed on 12 January 2008. 


\section{List of tables}

Table 1 Main meteorological characteristics of Akdarya river basin (Uzdavsuvloixa, 2002)

Table 2 Water resources balance feeding Akdarya reservoir (Uzdavsuvloixa, 2002)

Table 3 Volumes and water surface areas of Akdarya reservoir at full and minimum pool elevations from the creation of the reservoir (1982), for 1996 and 2003

Table 4 Comparison of reservoir volume and surface areas from experimental, kriging, and simulation (minimum, mean, median, maximum) of Akdarya reservoir 
Figures captions 


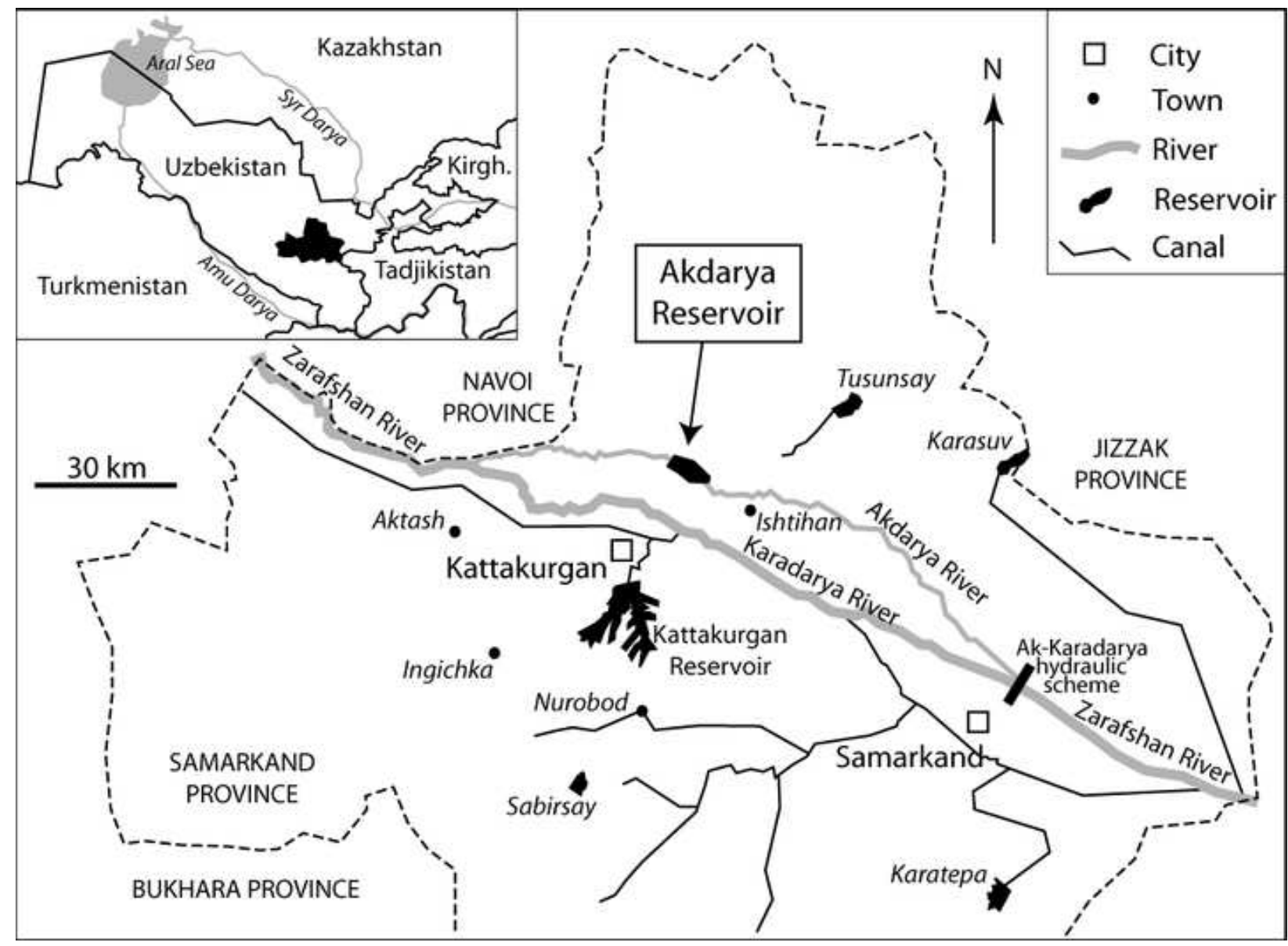

Fig. 1 Location of Akdarya reservoir in Sam arkand province of Uzbekistan 


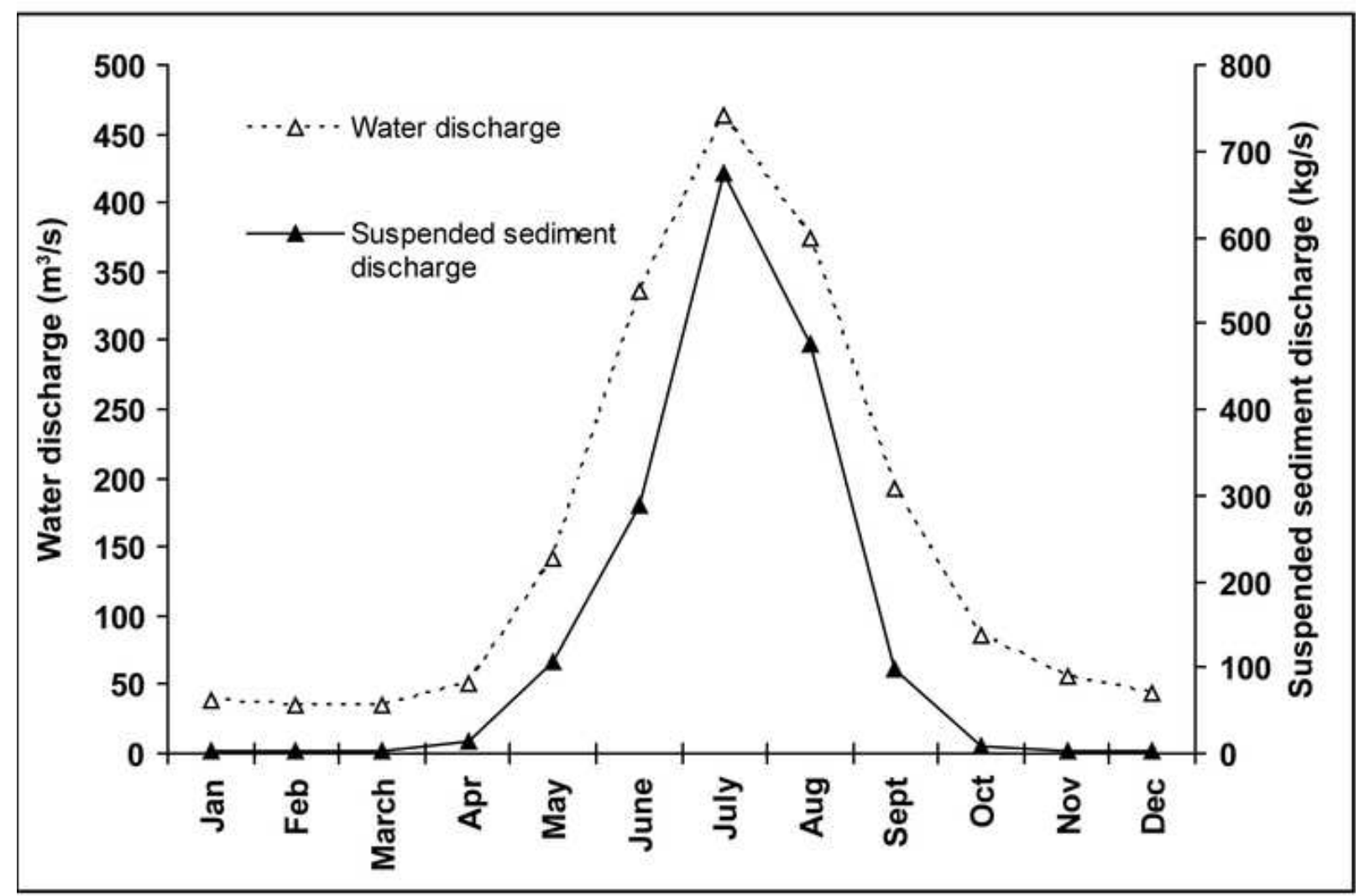

Fig. 2 Diagram of water discharge versus sediment discharge of Akdarya River (Uzdavsuvloixa, 2002) 


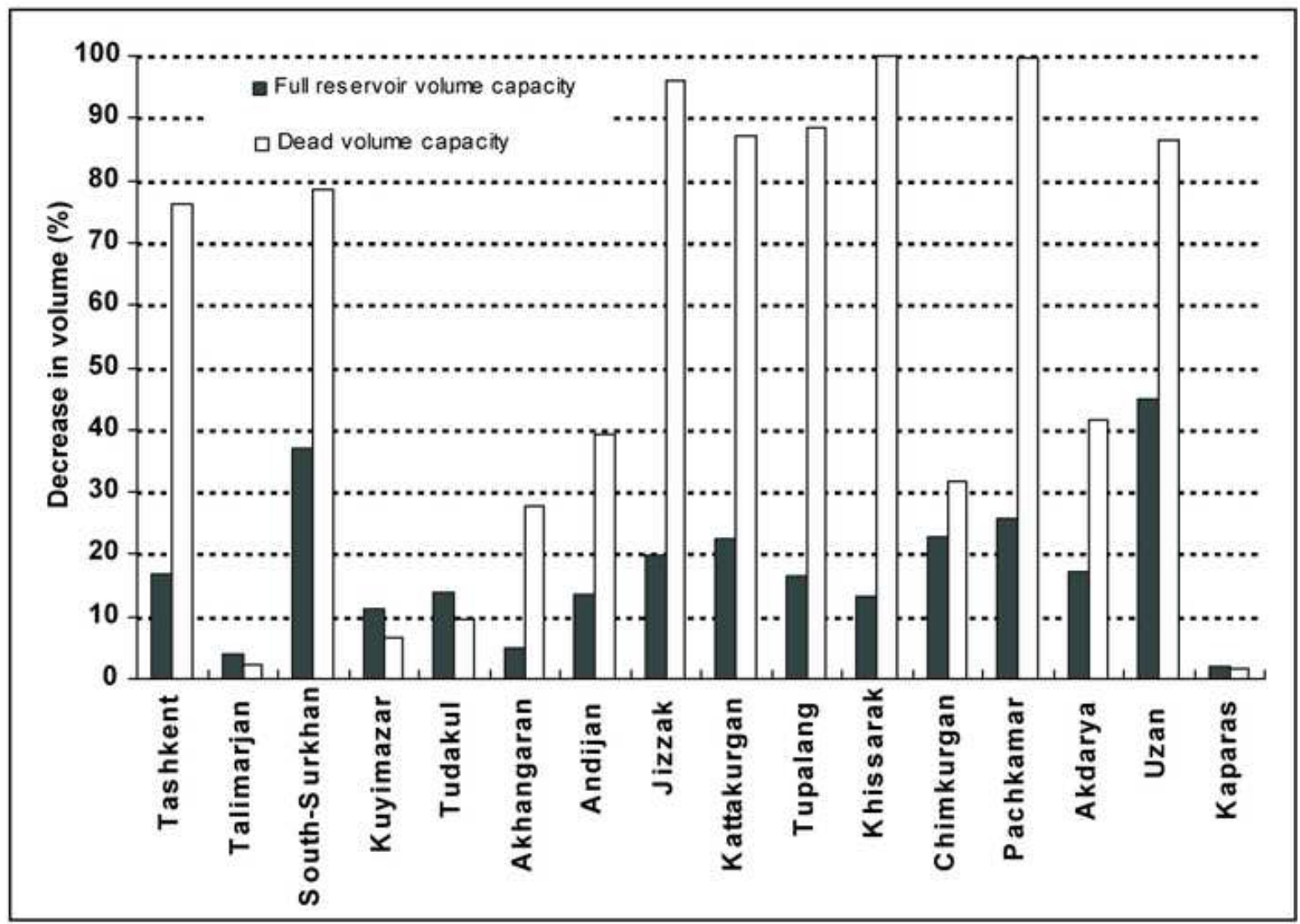

Fig. 3 Decrease in total and dead volume capacities due to sedimentation in 16 reservoirs in Uzbekistan. 


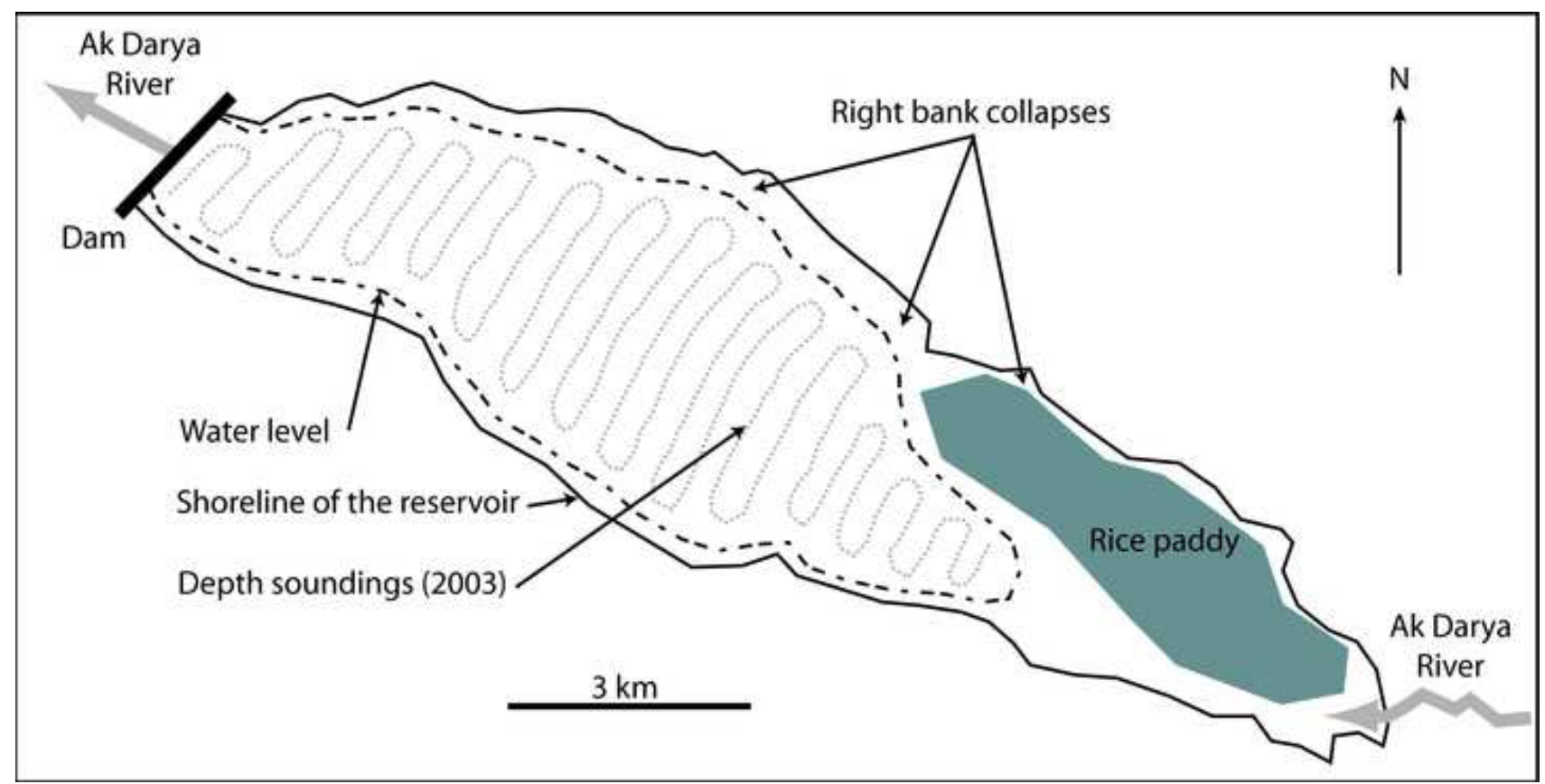

Fig. 4 Data measurements with bathymetric system CEEDUCER and current conditions of Akdarya reservoir in 2003 


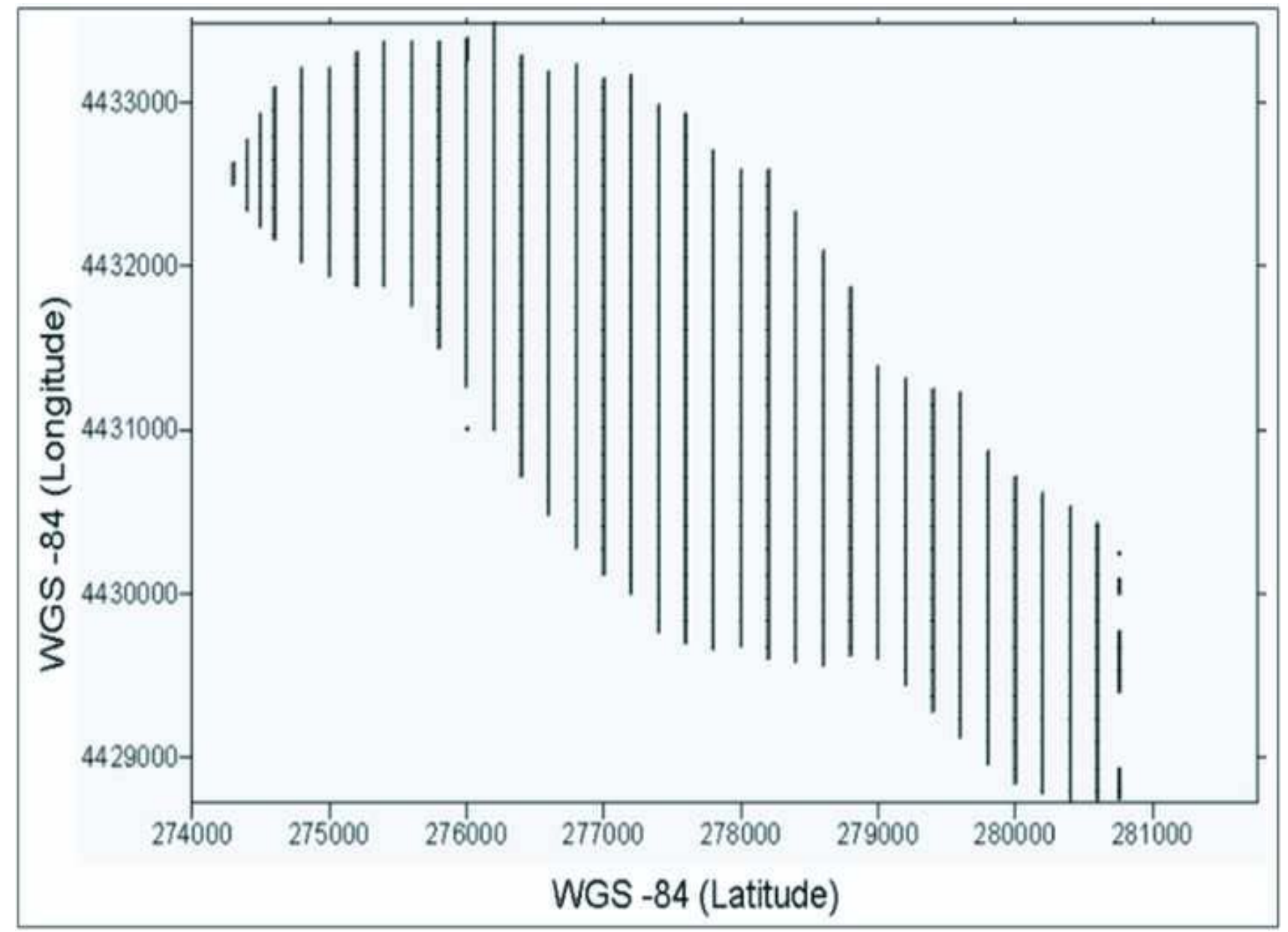

Fig. 5 Actual depth measurement points in Akdarya reservoir in 2003 (Bathymetric Center, 2003) 


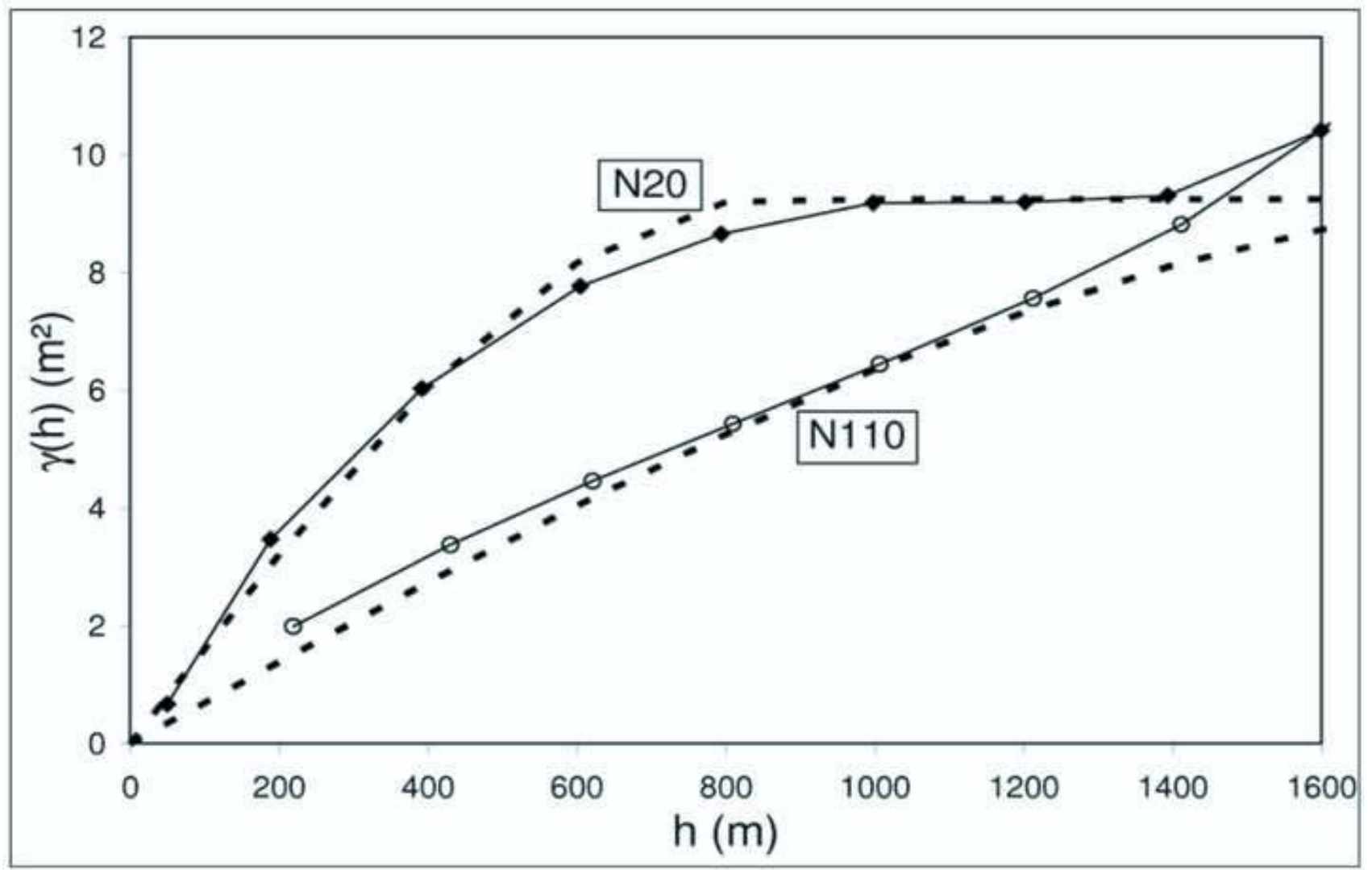

Fig. 6 Experimental semivariogram of reservoir bottom elevations direction N20 (smallest variance) and N110 (largest variance) of Akdarya reservoir. 


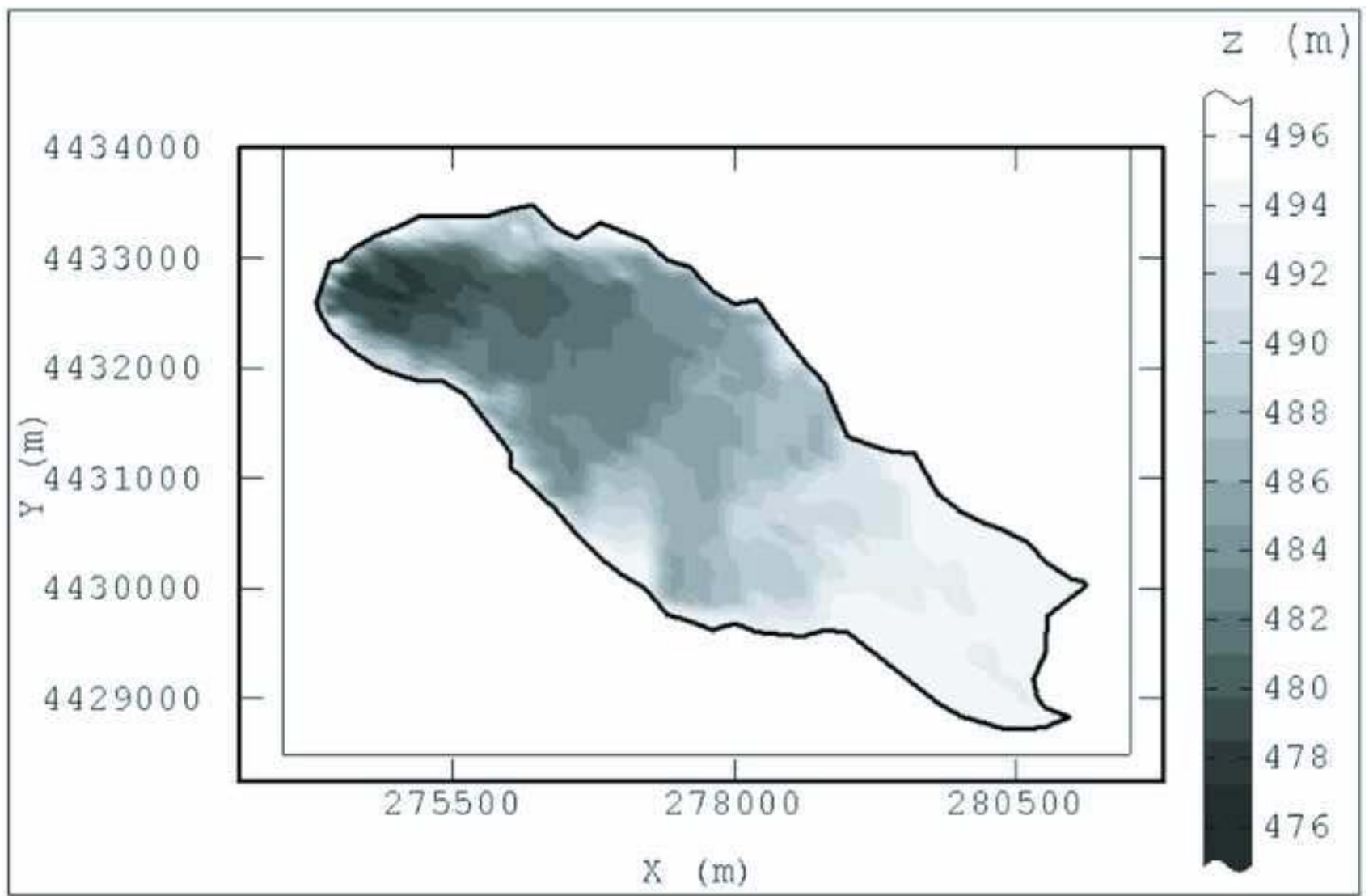

Fig. 7 Bathymetric map of Akdarya reservoir by kriging interpolation method 


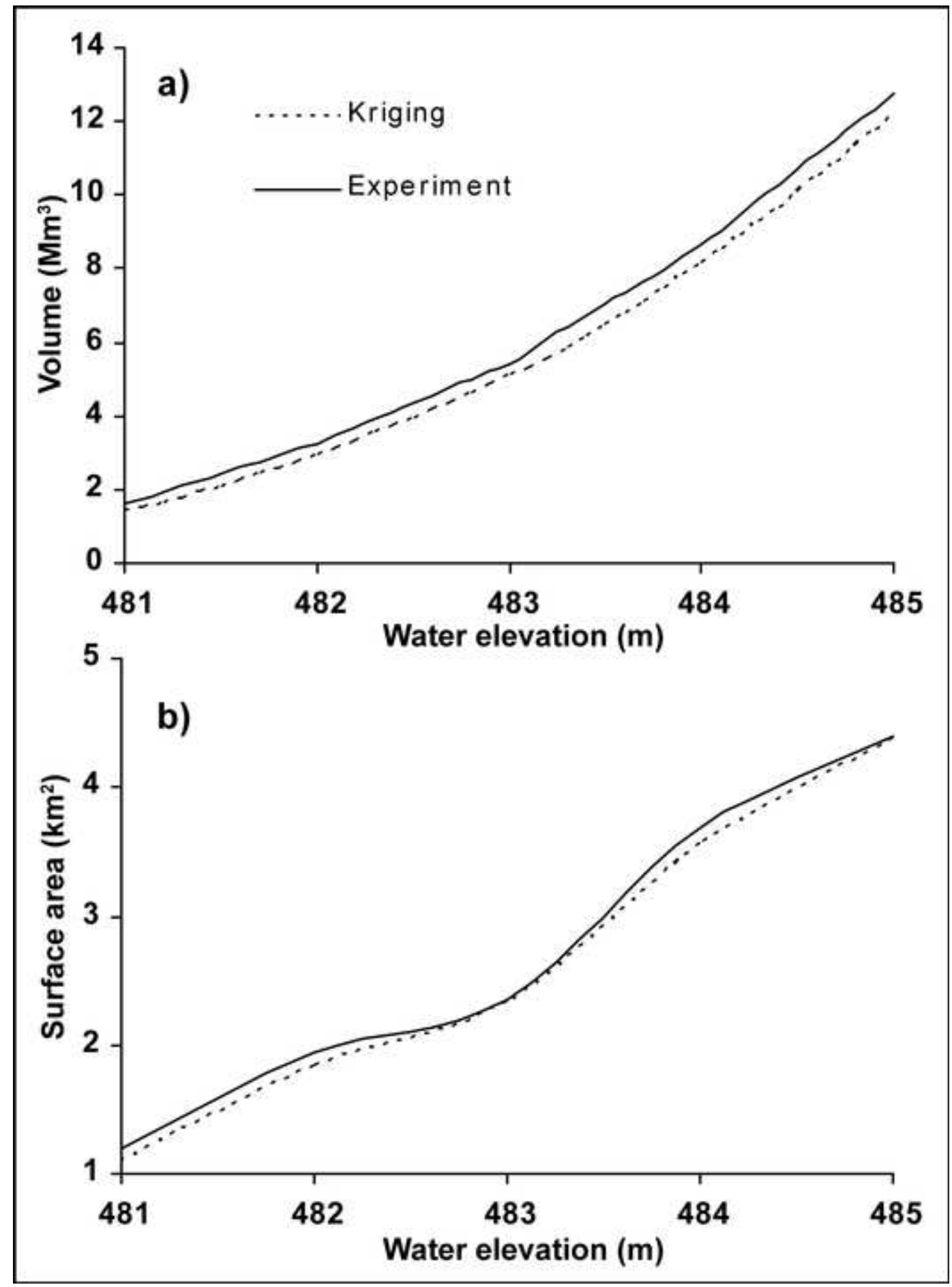

Fig. 8 Akdarya reservoir volume (a) and surface area (b) by kriging and experimental data (2003) 


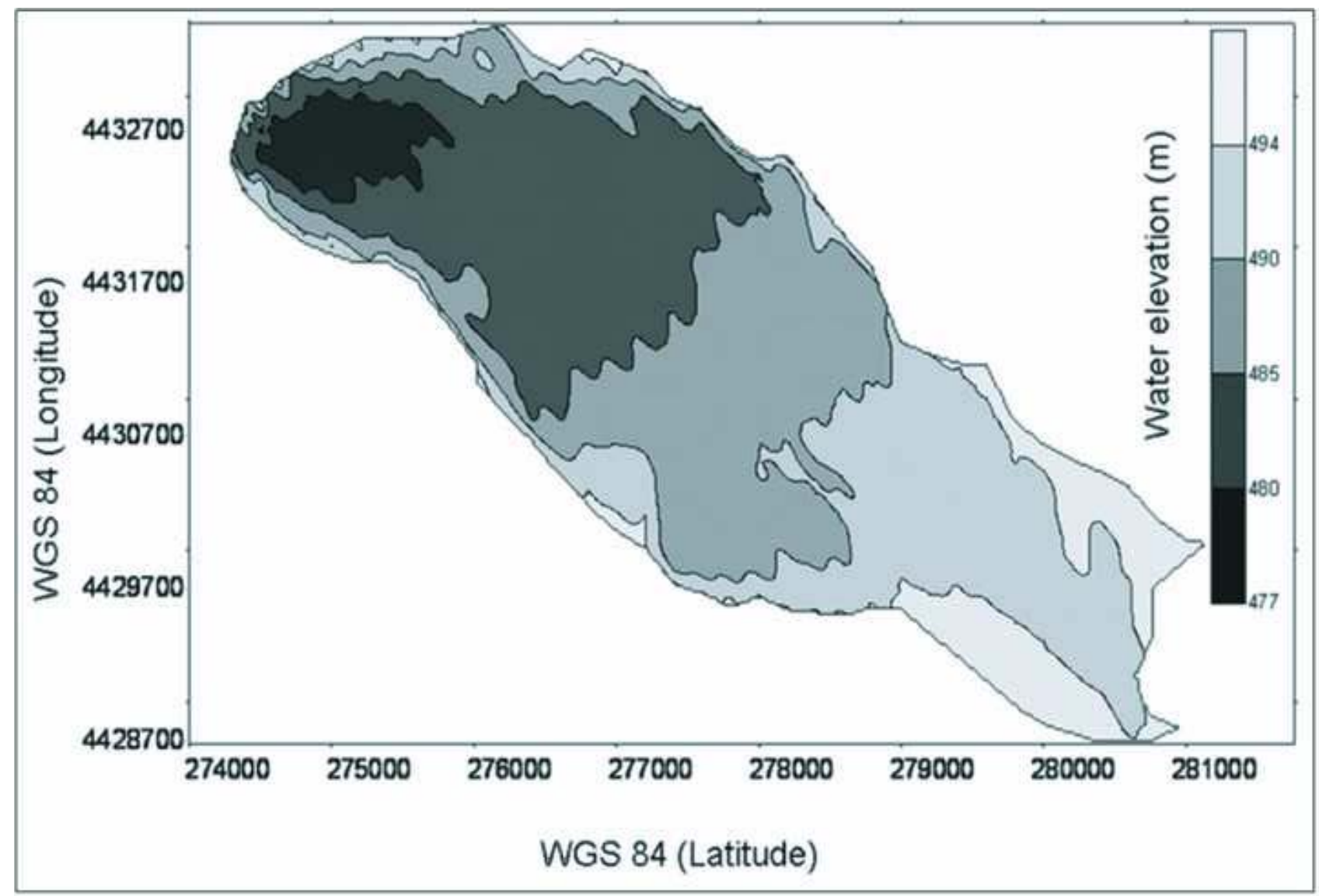

Fig. 9 Reservoir volume of Akdarya at different water elevations 


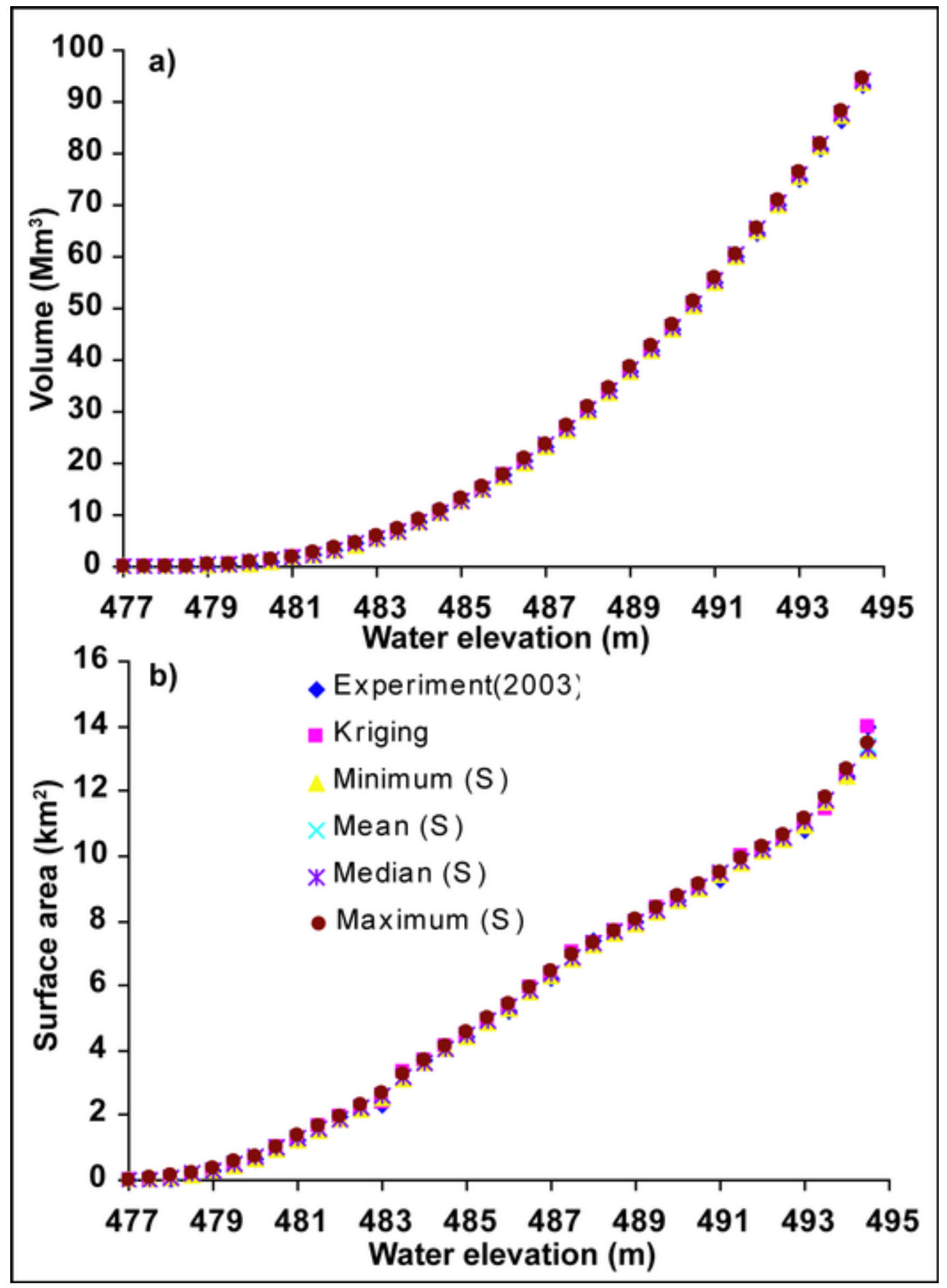

Fig. 10 Akdarya Reservoir volume (a) and surface area (b) vs water elevation for experimental, kriging and simulation 


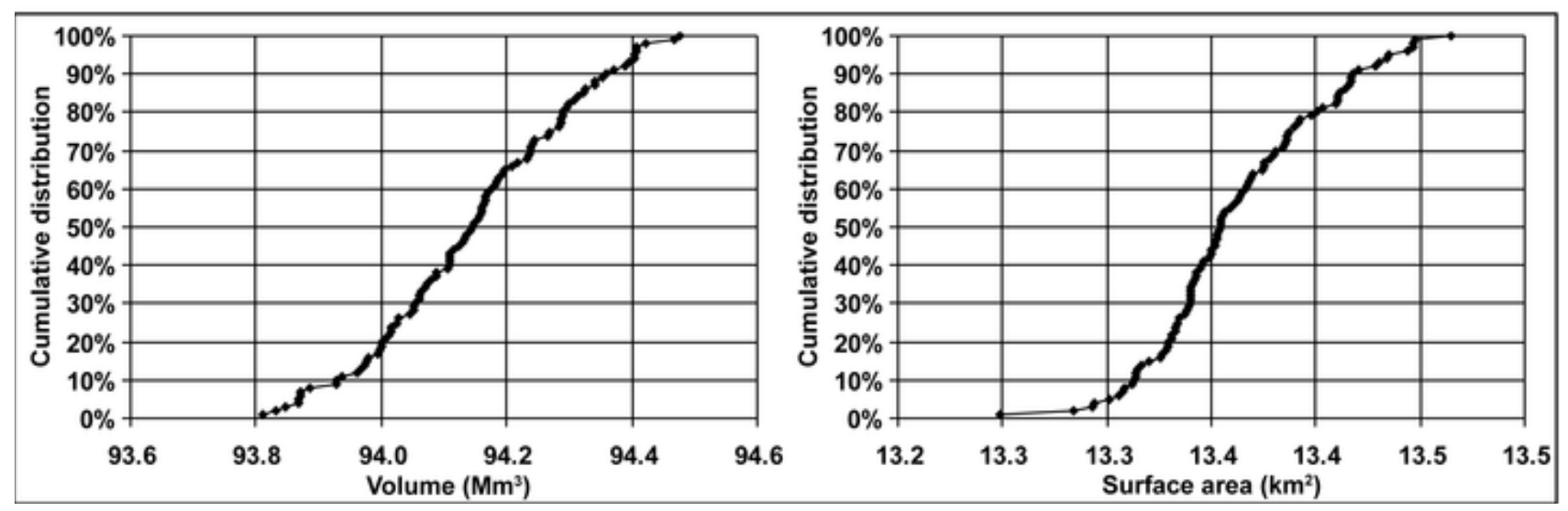

Fig. 11 Cumulative distribution of reservoir volume and area for a water elevation equal to $494.5 \mathrm{~m}$ (simulations outputs). 
Table 1.

\begin{tabular}{llllllllllllll}
\hline Characteristics & Jan & Feb & Mar & Apr & May & June & July & Aug & Sept & Oct & Nov & Dec & Year \\
\hline $\begin{array}{l}\text { Air temperature } \\
\left({ }^{0} \mathrm{C}\right)\end{array}$ & -1.9 & 1.8 & 7.2 & 13.9 & 20.0 & 24.9 & 27.2 & 25.1 & 19.1 & 11.0 & 5.9 & 1.4 & 13.0 \\
$\begin{array}{l}\text { Precipitation } \\
(\mathrm{mm})\end{array}$ & 42 & 42 & 56 & 48 & 22 & 4 & 0 & 0 & 1 & 11 & 23 & 33 & 282 \\
$\begin{array}{l}\text { Daily max. } \\
\text { precipitation } \\
(\mathrm{mm})\end{array}$ & 30 & 38 & 43 & 62 & 88 & 18 & 1 & 7 & 3 & 23 & 25 & 26 & 88 \\
$\begin{array}{l}\text { Humidity } \\
(\%)\end{array}$ & 80 & 77 & 76 & 67 & 54 & 38 & 34 & 36 & 39 & 52 & 66 & 80 & 58 \\
$\begin{array}{l}\text { Evaporation } \\
\text { (mm) }\end{array}$ & 30 & 20 & 16 & 33 & 110 & 200 & 254 & 223 & 142 & 75 & 54 & 43 & 1200 \\
$\begin{array}{l}\text { Mean monthly } \\
\text { wind speed } \\
(\mathrm{m} / \mathrm{sec})\end{array}$ & 2.1 & 2.7 & 2.8 & 2.8 & 2.6 & 2.4 & 2.5 & 2.1 & 2.0 & 1.8 & 2.0 & 1.9 & 2.3 \\
\hline
\end{tabular}


Table 2.

\begin{tabular}{lcc}
\hline \multicolumn{1}{c}{ Source of Discharge } & $\begin{array}{c}\text { Mean Water Year } \\
\left(\mathbf{M m}^{\mathbf{3}} \mathbf{)}\right.\end{array}$ & $\begin{array}{c}\text { Drought Year } \\
\mathbf{( M m}^{\mathbf{3}} \mathbf{)}\end{array}$ \\
\hline 1-Discharge from Zarafshan river & 250 & 200 \\
2-Springs & 160 & 100 \\
3-Irrigation and collector-drainage canals & 180 & 130 \\
TOTAL & 590 & 430 \\
Water intake & 230 & 210 \\
Discharge in the reservoir & 360 & 220 \\
\hline
\end{tabular}


Table 3.

\begin{tabular}{cccccc}
\hline & \multicolumn{2}{c}{ Full Pool Elevation } & & $\begin{array}{c}\text { Minimum Pool } \\
\text { Elevation }\end{array}$ \\
\hline Year & $\begin{array}{c}\text { Full Volume } \\
\text { Capacity } \\
\left(\mathrm{Mm}^{3}\right)\end{array}$ & $\begin{array}{c}\text { Water Surface } \\
\text { Area }\end{array}$ & $\begin{array}{c}\text { Useful Volume } \\
\text { Capacity } \\
\left(\mathrm{km}^{2}\right)\end{array}$ & $\begin{array}{c}\text { Dead Volume } \\
\text { Capacity } \\
\left(\mathrm{Mm}^{3}\right)\end{array}$ & $\begin{array}{c}\text { Water Surface } \\
\text { Area } \\
\left(\mathrm{km}^{2}\right)\end{array}$ \\
\hline 1982 & 112.5 & 12.7 & 110 & 2.5 & 3.5 \\
1996 & 100.7 & 11.67 & 98.5 & 2.2 & 1.64 \\
2003 & 93.17 & 13.97 & 91.71 & 1.46 & 0.92 \\
\hline
\end{tabular}


Table 4.

\begin{tabular}{|c|c|c|c|c|c|c|}
\hline \multicolumn{7}{|c|}{ Volume $\left(\mathrm{Mm}^{3}\right)$} \\
\hline \multirow{2}{*}{$\begin{array}{l}\text { Water } \\
\text { elevation } \\
\text { (m) }\end{array}$} & \multirow[t]{2}{*}{ Measured } & \multirow[t]{2}{*}{ Kriging } & \multicolumn{4}{|c|}{ Simulation } \\
\hline & & & Minimum & Mean & Median & Maximum \\
\hline 477 & 0.003 & 0.00074 & 0.0012 & 0.0044 & 0.0041 & 0.011 \\
\hline 480.5 & 1.12 & 1.05 & 1.07 & 1.16 & 1.16 & 1.24 \\
\hline 485 & 12.76 & 12.64 & 12.53 & 12.79 & 12.78 & 12.97 \\
\hline 490 & 46.04 & 46.27 & 46.11 & 46.41 & 46.41 & 46.77 \\
\hline 494.5 & 93.17 & 93.83 & 93.81 & 94.15 & 94.15 & 94.48 \\
\hline \multicolumn{7}{|c|}{ Surface $\left(\mathrm{km}^{2}\right)$} \\
\hline \multirow{2}{*}{$\begin{array}{l}\text { Water } \\
\text { elevation } \\
\text { (m) }\end{array}$} & \multirow[t]{2}{*}{ Measured } & \multirow[t]{2}{*}{ Kriging } & \multicolumn{4}{|c|}{ Simulation } \\
\hline & & & Minimum & Mean & Median & Maximum \\
\hline 477 & 0.0084 & 0.0036 & 0.0044 & 0.012 & 0.011 & 0.024 \\
\hline 480.5 & 0.95 & 0.98 & 0.94 & 0.98 & 0.98 & 1.04 \\
\hline 485 & 4.39 & 4.43 & 4.42 & 4.48 & 4.48 & 4.54 \\
\hline 490 & 8.63 & 8.66 & 8.62 & 8.68 & 8.68 & 8.73 \\
\hline 494.5 & 13.98 & 13.97 & 13.25 & 13.36 & 13.35 & 13.46 \\
\hline
\end{tabular}

